GRASAS Y ACEITES 65 (2)

April-June 2014, e020

ISSN-L: 0017-3495

doi: http://dx.doi.org/10.3989/gya.086913

\title{
Toxicological assessment of crude palm oil (Elaeis guineensis Jacq.) used in deep frying of akara (cowpea paste finger food)
}

\author{
I. Felzenszwalb ${ }^{\mathrm{a}}$, J.L. da Costa Mazzei ${ }^{\mathrm{b}}$, S. Feitosa ${ }^{\mathrm{c}}$, C.A. Fortes Aiub ${ }^{\mathrm{d}}$ and D.T. de Almeida ${ }^{\mathrm{c}, 凹}$ \\ ${ }^{a}$ Universidade do Estado do Rio de Janeiro, Instituto de Biologia Roberto Alcântara Gomes. Av 28 de Setembro, 87 fds. $4^{\circ}$ andar, \\ Vila Isabel 20551-030 - Rio de Janeiro, RJ-Brasil \\ ${ }^{b}$ Fundação Oswaldo Cruz, Far-Manguinhos - Instituto de Tecnologia em Fármacos. Rua Sizenando Nabuco, 100, Manguinhos, \\ 21041-250 - Rio de Janeiro, RJ-Brasil \\ ${ }^{c}$ Escola de Nutrição, Universidade Federal da Bahia, Av. Araújo Pinho, 32, Canela, Salvador-Bahia, CEP: 40110-150, Brazil \\ ${ }^{d}$ Universidade Federal do Estado do Rio de Janeiro, Departamento de Genética e Biologia Molecular, Rua Frei caneca 94, Centro, \\ 20211040 - Rio de Janeiro, RJ-Brasil \\ Corresponding author: deliata@uol.com.br; delia@ufba.br
}

Submitted: 28 August 2013; Accepted: 23 December 2013

SUMMARY: Akara is cowpea paste which is deep-fried in crude palm oil (CPO; Elaeis guineensis Jacq.) and sold as a street finger food in Brazil and Africa. During the food frying oils can form toxic decomposition products as total polar compounds (TPC), which can determinate oil degradation. The aim of this study was to assess the toxicity of CPO used in akara frying for 25 hours. Changes in the oil were determined by TPC quantification and mutagenicity using a Salmonella/microssome assay with Salmonella Typhimurium strains TA97, TA98, TA100 and TA102 with and without exogenous metabolic activation. Assuming that 25\% TPC is the maximum level permitted in frying oils and it ranged from 14.08 to $29.81 \%$, frying palm oil exceeded the limit. Nonetheless, no cytotoxic, mutagenic or genotoxic activity were detected in CPO used in the traditional akara frying process.

KEYWORDS: Micronucleus; Mutagenicity; Palm oil; Repeatedly fried cooking; Toxicology

RESUMEN: Evaluación toxicológica de aceite crudo de palma (Elaeis guineensis Jacq.) usado en fritura de akara (tapa de pasta de frijol). Akara es una tapa hecha de pasta de frijol frito en aceite de palma crudo (CPO; Elaeis guineensis), que se vende en las calles de Brasil y África. Durante la fritura de alimentos, los aceites pueden formar productos de descomposición tóxicos como los compuestos polares totales (TPC), que determinan la degradación del aceite. El objetivo de este estudio fue evaluar la toxicidad de CPO utilizado en 25 horas de frituras de akara. Los cambios en el aceite se determinaron mediante la cuantificación de TPC y ensayos de mutagenicidad en Salmonella/microsomas usando cepas de Salmonella Typhimurium TA97, TA98, TA100 y TA102 con y sin activación metabólica exógena. Se asume que el $25 \%$ de TPC es el nivel máximo permitido, los aceites de fritura oscilaron desde 14,08 hasta $29,81 \%$. Ningún CPO utilizado en el proceso de akara tradicional mostró ser citotóxico, ni tener actividad mutagénica o genotóxica.

PALABRAS CLAVE: Aceite de palma; Fritura repetida; Micronúcleos; Mutagenicidad; Toxicología

Citation/Cómo citar este artículo: Felzenszwalb I, da Costa Mazzei JL, Feitosa S, Fortes Aiub CA, de Almeida DT. 2014. Toxicological assessment of crude palm oil (Elaeis guineensis Jacq.) used in deep frying of akara (cowpea paste finger food). Grasas Aceites 65 (2): e020. doi: http://dx.doi.org/10.3989/gya.086913.

Copyright: (C) 2014 CSIC. This is an open-access article distributed under the terms of the Creative Commons Attribution-Non Commercial (by-nc) Spain 3.0 Licence. 


\section{INTRODUCTION}

Palm oil is derived from the fruit of the palm tree Elaeis Guineensis Jacq. and is consumed as crude palm oil (CPO) in Africa, Southeast Asia and Brazil. Unrefined palm oil is orange-red in color and contains triglycerides with approximately $50 \%$ saturated fatty acids, $40 \%$ monounsaturated and 10\% polyunsaturated fatty acids, along with carotenoids and vitamin E (Norhaizan et al., 2013; Sampaio et al., 2013). By fractionation, a liquid fraction (palm olein, rich in unsaturated compounds) and a solid fraction (palm stearin, rich in saturated compounds) can be obtained and used for different purposes in the food industry (Lin, 2011).

In Brazil, crude palm oil is known as azeite de dendê and it is an ingredient in most dishes from Bahia, such as moqueca, vatapá, xinxin de galinha, caruru, and acarajé (akara) (Almeida et al., 2013; Oliveira, 2009). Akara is a paste of cowpea (Vigna unguiculata $\mathrm{L}$. Walp) sold as a street finger food and it has been described as the most common food product containing cowpeas in Africa (Reber et al., 1983) and Brazil. It's also a cultural and touristic Brazilian icon made and sold by typically clothed women called baianas de acarajé (IPHAN, 2005). In the process of making akara, cowpea is split, decorticated and macerated into a paste. After seasoning with grated onions and salt, akara paste is whipped, shaped into balls with a wooden spoon and deep-fried in CPO.

During the frying process, the oil undergoes hydrolysis, oxidation and polymerization reactions leading to changes in flavor stability and quality, color, and texture of the fried food and its nutritional quality (Dobarganes, 2000a; Saguy and Dana, 2003; Velasco et al., 2008). The frying temperature and time, type of heating, frying oil composition, oil turnover rate, oxygen content, antioxidants and type of fryer affect the deterioration of oil during deep-fat frying (Soriano et al., 2002).

These chemical reactions in frying oil originate volatile products, which are partially eliminated during frying and new non-volatile compounds are also formed (Saguy and Dana, 2003). These new compounds have higher polarity and constitute the so-called total polar compounds (TPC), which include triglyceride polymers (TGP), triglyceride dimers (TGD), oxidized triglyceride monomers (oxTGM), diglycerides (DG) and free fatty acids (FFA) (Dobarganes et al., 2000b). In general, fresh refined oils contain total polar compounds ranging from $3.2 \%$ to $3.8 \%$. It is recommended that frying oils which contain more than $24-27 \%$ TPC should be discarded (Berger, 2005; Saguy and Dana, 2003).

Several studies were performed to evaluate the mutagenic potential in vegetable oils used in deep frying (Fong et al., 1980; Scheutwinkel-Reich et al.,
1981; Taylor et al., 1982; Van Gastel et al., 1984), the effects of repeated ingestion of heated palm oil by rats (Adam et al., 2009; Farag et al., 2010; Isong et al., 1997), and they showed that the fraction of polar compounds isolated from the oxidized oils is toxic to laboratory animals (Pantzaris, 1998). Besides that, the Ames test (Salmonella/microsome assay) is a rapid, safe and predictive test for mutagenicity in mammals (Claxton et al., 1987; Maron and Ames, 1983; Carpes et al., 2013), in which Hageman et al. (1988) have detected mutagenic activity in polar material obtained from deep-frying fats.

The Ames test is a widely used methodology to detect mutagenic chemicals (Claxton et al., 1987; Maron and Ames, 1983; Carpes et al., 2013), however, bacteria is less able to repair DNA damage than a mammals ability. A macrophage lineage is used due to its ability to promote responses involving oxidative stress. In this way, RAW 264.7 is one of the most commonly used for giving the clearest results and being extremely sensitive to lipopolysaccharide endotoxin from gram-negative bacteria such as Salmonella (Claxton et al., 1987; Maron and Ames, 1983).

Changes in oil quality during deep frying are still a major issue from the health perspective. Nevertheless, there are few studies in the literature regarding the consequences of consuming CPO deep fried foods. It has been observed that the baianas de acarajé sell akara daily for $5 \mathrm{~h}$ hours and continuously reuse the fried palm oil, hence this frying oil may have toxic compounds present. Therefore, the aim of this work was to evaluate CPO mutagenic and genotoxic activities before and after 25 hours of frying akara, and to quantify its TPC $(\%)$ contents.

\section{MATERIALS AND METHODS}

\subsection{CPO sample and frying process}

$30 \mathrm{~L}$ of integral CPO (a mixture of liquid and solid phases) industrialized at Nazaré city (state of Bahia, Brazil) and conditioned in two tinplate cans with a capacity of $15 \mathrm{~L}$ each were purchased at São Joaquim Fair, in Salvador (Bahia). This oil was placed in a stainless steel recipient and heated up to $45^{\circ} \mathrm{C}$, allowing oil fusion and homogenization to be used in frying. At first, $20 \mathrm{~mL}$ (time 0) of it were filtered in a glass wool filter, inerted with nitrogen gas and stored in an amber bottle at $-20{ }^{\circ} \mathrm{C}$ (Jorge and Gonçalves, 1998) and thawed for analysis (initial sample, CPO).

The preparation of akara was performed by a baiana de acarajé according to her traditional practice. $5 \mathrm{~kg}$ of crude mass of akara were bought daily from her traditional source at the same fair. Frying was always performed outdoors. First the raw mass was placed in an aluminum pan and seasoned with 
grated onions and salt, then whipped and shaped into balls (60-80 g each) with a wooden spoon. Then, $5 \mathrm{~L}$ of $\mathrm{CPO}$ in an enameled pan were heated for 12 minutes in the presence of an onion (baiana's traditional practice - an intention of making the oil quality lasts longer the oil quality longer during frying). Subsequently, 5 of those balls were successively added to the oil and deep-fried during approximately 6 minutes, with some intervals in which the oil remained with only the onion, while the baiana whipped the mass again, and a total of 110 akaras/ day was obtained - simulating akara's average quantity at the baiana's point of sale (Rogerio, 2010).

The total frying time per day was 5 intermittent hours and the frying process was performed on 5 consecutive days - totaling 25 hours. The temperature ranged from 143 to $188{ }^{\circ} \mathrm{C}$ in the beginning (day 1) and $159-178^{\circ} \mathrm{C}$ in the end (day 5).

Every frying day began with $5 \mathrm{~L}$ in the enameled pan. On day 1 , only fresh oil was used, and on subsequent days a mixture of the previous day's oil (used oil) was made with fresh oil. The oil turnover was performed daily with $2 \mathrm{~L}$ at the most. On days 1 and 2 only fresh CPO was added, and on the other days, the replacement was made with a mixture of fresh plus used oil, according to the baiana's techniques.

Then, at the end of each frying day, the oil was left undisturbed in a pan with a lid, at room temperature, until the food waste settled, and was filtered afterwards, stored until the next frying day and the same procedure was repeated over four subsequent days, for a total time of 25 hours. At the end of each day and the frying process ( 25 hours), a new aliquot of $20 \mathrm{~mL}$ was filtered in a glass wool filter, obtaining the last sample (FPO of frying) and the others for TPC (\%) content analysis.

\subsection{Total Polar compounds}

Total polar compound (TPC) content was determined gravimetrically according to a mini column method described previously, with slight modifications (Dobarganes et al., 2000b). In brief, approximately $0.5 \mathrm{~g}$ of crude palm oil were dissolved in the elution solvent and introduced into a glass column filled with a silica gel slurry and elution solvent. This elution solvent was a mixture of light petroleum (b.p. $40-60{ }^{\circ} \mathrm{C}$ ) and diethyl ether 94:6 (v:v). A chromatographic glass column with an internal diameter of $1 \mathrm{~mm}$ and a length of $15 \mathrm{~mm}$, containing $5 \mathrm{~g}$ of silica gel (with a particle size $0.063-0.200$ $\mathrm{mm}$ and $70-230$ mesh) adjusted to a water content of $5 \%$ was used. Non-polar compounds were eluted with $60 \mathrm{~mL}$ of elution solvent and the polar compound fraction was eluted with $50 \mathrm{~mL}$ diethyl ether. A dropping funnel was used and the flow rate was adjusted to approximately $1.5 \mathrm{~mL} \cdot \mathrm{min}^{-1}$. Solvent was removed by rotary evaporation and the flask was flushed with a stream of nitrogen to ensure dryness. The completeness of fractionation was evaluated by analytical thin-layer chromatography (TLC) with an elution system of petroleum ether:diethyl ether:acetic acid (70:40:1; v:v:v).

The reported data of TPC were obtained from duplicate measurements of each sample and expressed in terms of the mean and standard error (SE). A regression analysis was also applied to these data.

\subsection{Salmonella/microsome assay}

The mutagenic evaluation of CPO and FPO was performed by the pre-incubation method of Salmonella/microssome assay as described by Maron and Ames (1983), with slight modifications (Mortelmans and Zeiger, 2000). Briefly, $100 \mu \mathrm{L}$ of different concentrations of CPO or FPO (all dilutions were in DMSO) and $100 \mu \mathrm{L}$ of stationary growth cultures of Salmonella Typhimurium strains TA97, TA98, TA100, and TA102 were added to 500 $\mu \mathrm{L}$ of $0.2 \mathrm{M}$ of a sodium phosphate buffer ( $\mathrm{pH}$ 7.4) or to $500 \mu \mathrm{L}$ of an $\mathrm{S} 9$ mix. After pre-incubation of the mixture at $37^{\circ} \mathrm{C}$ for $30 \mathrm{~min}, 2 \mathrm{~mL}$ of top agar were added to it and the contents poured onto a minimal glucose agar plate. The plates were incubated at $37^{\circ} \mathrm{C}$ and the numbers of $\mathrm{His}^{+}$were scored after 72 h. Each assay (in triplicate) was repeated twice to confirm the results.

Aroclor 1254-induced rat liver S9 fraction was purchased from Molecular Toxicology Inc. (Moltox $^{\mathrm{TM}}$, USA). The metabolic activation mixture (S9 mix) was prepared according to Maron and Ames (1983) and used as described earlier (Aiub et al., 2003). The criterion for a positive mutagenic response was the number of reverting colonies in the test assay amounting to at least twice the number of spontaneous reverting (Mutagenic Index, MI $\geq 2$ ) (Maron and Ames, 1983).

The mutagenic response was considered positive when the number of revertant colonies in the test was at least twice the number of spontaneous revertants and no cytotoxicity was detected (survival rates $<70 \%$ ). Significant statistical differences between negative and tested concentrations under the same experimental conditions were verified by statistical analysis (Student t-test, $\mathrm{p} \leq 0.05$ ) (Stankevicins et al., 2008).

\subsection{Survival experiments}

To determine the citotoxic effect of CPO and FPO, samples from the pre-incubation assay mixture in the Salmonella/microssome assay were diluted in $0.9 \% \mathrm{NaCl}(\mathrm{w} / \mathrm{v})$ to obtain a suspension containing $2 \times 10^{2}$ cells $\cdot \mathrm{mL}^{-1}$. An aliquot of 100 $\mu \mathrm{L}$ of this suspension was poured onto a nutrient agar plate. The plates were incubated at $37{ }^{\circ} \mathrm{C}$ for $24 \mathrm{~h}$ and colonies were counted. Citotoxicity was 
considered positive when the cell survival rate was $<70 \%$ of the rate observed for the negative control (Aiub et al., 2003).

\subsection{RAW 264.7 cell culture}

A murine macrophage cell line was used from a culture at confluence and was incubated in an atmosphere of $5 \% \mathrm{CO}_{2}$, at a temperature of 37 ${ }^{\circ} \mathrm{C}$. Cell detachment was carried out mechanically by scraping. After that the suspension was centrifuged at $5000 \mathrm{rpm}$ for $5 \mathrm{~min}$ and cells were re-suspended in Modified Eagle Medium (MEM) $\mathrm{Ca}^{2+}, 1.8 \mathrm{mM}$ (Gibco®) supplemented with $10 \%$ fetal bovine serum, $1.76 \mathrm{~g} \cdot \mathrm{L}^{-1}$ of $\mathrm{NaHCO}_{3}, 0.88$ g. $\mathrm{L}^{-1}$ of pyruvate, $22 \mathrm{mg} \cdot \mathrm{L}^{-1}$ of aspartic acid and $17 \mathrm{mg} \cdot \mathrm{L}^{-1}$ of ${ }_{\mathrm{L}}$-serine. Cell viability was determined after trypan blue staining and the cells were plated on 24-well plates at a density of $2 \times 10^{5}$ cells/well and then incubated for $24 \mathrm{~h}$.

\subsection{Micronucleus assay}

The micronucleus assay was performed as previously described (Aiub et al., 2011), with modifications. Cells were treated with $100 \mu \mathrm{L}$ of various dilutions of $\mathrm{CPO}$ or FPO in DMSO, corresponding to $10 \%$ of the total volume of each well and then the plates were incubated for $24 \mathrm{~h}$. After this period, the medium was removed from the wells, cells were washed with $1 \mathrm{~mL}$ of MEM Ca ${ }^{2+}, 1.8 \mathrm{mM}$ and reincubated, and after that with $1 \mathrm{~mL}$ of $\mathrm{MEM} \mathrm{Ca}^{2+}$, $1.8 \mathrm{mM}$, supplemented with fetal bovine serum for 24 $\mathrm{h}$ in an atmosphere of $5 \% \mathrm{CO}_{2}$. N-methyl-N-nitro$\mathrm{N}$-nitrosoguanidine (MNNG) $0.5 \mu \mathrm{M}$ was used as positive control. The medium was then replaced with cold Carnoy's fixative ( 3 parts methanol to 1 of part glacial acetic acid) for $15 \mathrm{~min}$. Fixed cells were washed with McIlvaine buffer $\left(21 \mathrm{~g} \cdot \mathrm{L}^{-1}\right.$ of citric acid and $36 \mathrm{~g} \cdot \mathrm{L}^{-1}$ of $\mathrm{Na}_{2} \mathrm{HPO}_{4}, \mathrm{pH} 7.0$ ) for 2 minutes and left to dry at room temperature. Afterwards, the cells were stained with 4'-6-diamidino-2-phenylindole (DAPI) $\left(0.2 \mu \mathrm{g} \cdot \mathrm{mL}^{-1}\right)$, dissolved in McIlvaine buffer for $40 \mathrm{~min}$. Then, the cells were washed twice with McIlvaine buffer and left to dry again at room temperature.

To determine the mitotic index and number of micronucleated cells, as well as percentages of necrotic and apoptotic cells, 1000 cells per concentration were analyzed in a fluorescence microscope (Reichert Univar) at an excitation wavelength of $350 \mathrm{~nm}$. This experiment was conducted in quintuplicate. The data were analyzed using a one-way ANOVA and the Tukey-Kramer multiple comparison test. Results were considered to be statistically significant at $\mathrm{p}<0.05$ (Aiub et al., 2011, Carpes et al., 2013). GraphPad Instat ${ }^{\circledR}$ software, version 3.01 (GraphPad Software, Inc., USA) was used for all analyses.

\section{RESULTS AND DISCUSSION}

\subsection{Mutagenic activity}

There was no significant $(\mathrm{p}>0.05)$ increase in the number of reverting colonies at any of the tested concentrations of CPO and FPO over the respective negative control plates in all four tested strains, both with or without the $\mathrm{S} 9 \mathrm{mix}$ (Tables 1 and 2).

\subsection{Micronucleus evaluation}

The results from the assay with CPO and FPO are presented in Table 3. Both samples did not induce micronuclei formation, apoptosis or necrosis on macrophage cells. Moreover, they did not induce an increase in mitotic division. There was no significant difference between the results obtained with the oils sampled before and after frying $(\mathrm{p}<0.05)$.

\subsection{Total Polar compounds}

TPC contents increased linearly with frying time with high correlation coefficients $\left(\mathrm{R}^{2}=0.96\right.$; $\mathrm{TPC}=15.24+0.6$ time) (Table 4). After 25 hours of heating, the oil showed around 29\% polar compounds, above the established limit in most of the current regulation regarding the discharging of frying oils and fats for human consumption (Berger, 2005; Saguy and Dana, 2003). It was observed that the values were higher from $15 \mathrm{~h}$ of frying (Table 4), due to the greater heating time and replenishment with reused oil.

Crude palm oil is largely used in Brazilian cuisine and it is essential in akara deep frying. The latter is now regarded as one of Brazil's immaterial national treasures (IPHAN, 2005) and a cultural and touristic icon in the city of Salvador (Bahia, Brazil). During deep-frying, the high temperatures used in the presence of oxygen and water induced important chemical changes in the palm oil, inevitably reducing its shelf life and directly affecting its nutritional characteristics (Matthäus, 2007). Therefore, it is necessary to carry out toxicological studies to determine the security of the CPO used in this process.

No mutagenic or citotoxic activity were detected in the CPO used in the traditional akara frying process in all tested strains (Tables 1 and 2). Furthermore, it was observed that CPO did not induce genotoxic potential in the micronucleus assay in macrophages (Table 3). These results were contrary to the expected ones since the TPC content in the analyzed frying oil sample $(25 \mathrm{~h})$ exceeded the considered safe limit for health (Table 4) (Berger, 2005). Nevertheless, some researches had found no mutagenic activity in deepfrying oils (Scheutwinkel-Reich et al., 1981; Taylor et al., 1982; Van Gestel et al., 1984), and only Fong 
Toxicological assessment of crude palm oil (Elaeis guineensis) used in deep frying of akara (cowpea paste finger food) $\bullet 5$

TABLE 1. Mutagenic evaluation of crude palm oil before akara frying (CPO) in strains TA97, TA98, TA100 and TA102 of S. Typhimurium in the presence and absence of metabolic activation (S9)

\begin{tabular}{|c|c|c|c|c|c|c|c|}
\hline \multirow[b]{2}{*}{ Strain } & \multirow[b]{2}{*}{ CPO } & \multicolumn{3}{|c|}{-S9 } & \multicolumn{3}{|c|}{ +S9 } \\
\hline & & Mean $\pm S^{a}{ }^{a}$ & M.I $^{\mathbf{b}}$ & $\%$ Survival $^{\mathrm{c}}$ & Mean \pm SD $^{a}$ & M.I $^{\text {b }}$ & $\%$ Survival $^{\mathrm{c}}$ \\
\hline \multirow[t]{7}{*}{ TA97 } & 0 & $132 \pm 22$ & 1.0 & 100 & $107 \pm 14$ & 1.0 & 100 \\
\hline & $1: 128$ & $138 \pm 38$ & 1.0 & 97 & $130 \pm 19$ & 1.2 & 100 \\
\hline & $1: 64$ & $134 \pm 11$ & 1.0 & 90 & $114 \pm 9$ & 1.1 & 100 \\
\hline & $1: 32$ & $115 \pm 14$ & 0.9 & 91 & $119 \pm 15$ & 1.1 & 100 \\
\hline & $1: 16$ & $123 \pm 28$ & 0.9 & 90 & $134 \pm 11$ & 1.2 & 100 \\
\hline & $1: 8$ & $158 \pm 66$ & 1.2 & 89 & $118 \pm 6$ & 1.1 & 100 \\
\hline & $\mathrm{PC}$ & $483 \pm 62$ & 3.7 & 100 & $1016 \pm 418$ & 9.5 & 100 \\
\hline \multirow[t]{7}{*}{ TA98 } & 0 & $27 \pm 4$ & 1.0 & 100 & $42 \pm 3$ & 1.0 & 100 \\
\hline & $1: 128$ & $22 \pm 2$ & 0.8 & 100 & $42 \pm 4$ & 1.0 & 92 \\
\hline & $1: 64$ & $21 \pm 3$ & 0.8 & 100 & $45 \pm 8$ & 1.1 & 100 \\
\hline & $1: 32$ & $20 \pm 3$ & 0.8 & 100 & $37 \pm 4$ & 0.9 & 90 \\
\hline & $1: 16$ & $22 \pm 12$ & 0.8 & 100 & $56 \pm 5$ & 1.3 & 100 \\
\hline & $1: 8$ & $31 \pm 11$ & 1.1 & 100 & $64 \pm 6$ & 1.5 & 100 \\
\hline & $\mathrm{PC}$ & $145 \pm 5$ & 5.4 & 90 & $224 \pm 16$ & 5.3 & 86 \\
\hline \multirow[t]{7}{*}{ TA100 } & 0 & $70 \pm 8$ & 1.0 & 100 & $186 \pm 25$ & 1.0 & 100 \\
\hline & $1: 128$ & $68 \pm 40$ & 1.0 & 100 & $189 \pm 17$ & 1.0 & 100 \\
\hline & $1: 64$ & $68 \pm 47$ & 1.0 & 100 & $190 \pm 12$ & 1.0 & 100 \\
\hline & $1: 32$ & $86 \pm 4$ & 1.2 & 100 & $216 \pm 5$ & 1.2 & 99 \\
\hline & $1: 16$ & $99 \pm 13$ & 1.4 & 100 & $221 \pm 1$ & 1.2 & 100 \\
\hline & $1: 8$ & $65 \pm 9$ & 0.9 & 99 & $231 \pm 11$ & 1.2 & 100 \\
\hline & $\mathrm{PC}$ & $444 \pm 6$ & 6.0 & 100 & $2304 \pm 153$ & 12.4 & 100 \\
\hline \multirow[t]{7}{*}{ TA102 } & 0 & $345 \pm 64$ & 1.0 & 100 & $315 \pm 31$ & 1.0 & 100 \\
\hline & $1: 128$ & $356 \pm 45$ & 1.0 & 83 & $431 \pm 88$ & 1.4 & 100 \\
\hline & $1: 64$ & $301 \pm 15$ & 0.9 & 84 & $374 \pm 23$ & 1.2 & 100 \\
\hline & $1: 32$ & $337 \pm 18$ & 1.0 & 79 & $332 \pm 74$ & 1.1 & 100 \\
\hline & $1: 16$ & $312 \pm 10$ & 0.9 & 88 & $297 \pm 4$ & 0.9 & 92 \\
\hline & $1: 8$ & $295 \pm 39$ & 0.9 & 87 & $416 \pm 23$ & 1.3 & 87 \\
\hline & $\mathrm{PC}$ & $2207 \pm 286$ & 6.4 & 89 & $1016 \pm 103$ & 3.2 & 100 \\
\hline
\end{tabular}

${ }^{a}$ Number or revertant colonies per plate: mean values and standard deviation (SD) of at least three experiments; ${ }^{b} \mathrm{MI}$ : Mutagenic index: number of $\mathrm{His}^{+}$induced in the sample/number of spontaneous $\mathrm{His}^{+}$in the negative control; ${ }^{\mathrm{c}} \mathrm{Survival}$ calculated in relation to the negative control. Concentration 0 refers to the negative control (solvent): $100 \mu \mathrm{L}$ of DMSO. The doses of the positive controls (PC) per plate in the absence of S9 mix were $0.5 \mu \mathrm{g}$ of 4-nitroquinoline-1-oxide to TA97 and TA98; $1.0 \mu \mathrm{g}$ of Sodic Azide to TA100 and $0.5 \mu \mathrm{g}$ of Mitomicin C to TA102. The doses per plate of the positive

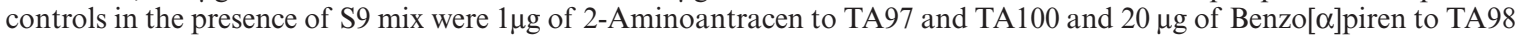
and TA102. Cytotoxicity was detected when survival rates $<70 \%$.

et al. (1980) had observed mutagenicity in peanut oil, however it had been correlated to an aflatoxin $\mathrm{B} 1$ contamination in the oil.

As already mentioned, TPC include TGP, TGD, oxTGM, DG, and FFA (Dobarganes et al., 2000b). As DG is measured as a fraction of TPC, it may be misleading to use TPC in judging oil quality. The higher amounts of total polar compounds in palm oils are mainly due to a higher level of DG contents $(4.0-7.5 \%)$ compared to other vegetable oils (2-3\%) (Berger, 2005; DeMarco et al., 2007). Otherwise, the CPO processing in Bahia displays high FFA \%, a consequence of the poor condition of the oil extraction (Almeida et al., 2013). Thus TPC elevation in samples (CPO and FPO) may be due to the predominance of such fractions which are not associated with the toxicity of heated oils (González-Munõz et al., 1998; Morita et al., 2008).

One unique characteristic of crude palm oil is its high content of carotenoids and tocopherols. Carotenoids, which impart to $\mathrm{CPO}$ its distinctive orange-red color, together with tocopherols and tocotrienols contribute to stability. A research made 
TABLE 2. Mutagenic evaluation of crude palm oil after akara frying (FPO) in strains TA97, TA98, TA100 and TA102 of S. Typhimurium in the presence and absence of metabolic activation (S9)

\begin{tabular}{|c|c|c|c|c|c|c|c|}
\hline \multirow[b]{2}{*}{ Strain } & \multirow[b]{2}{*}{ FPO } & \multicolumn{3}{|c|}{$-\mathrm{S} 9$} & \multicolumn{3}{|c|}{+ S9 } \\
\hline & & Mean $\pm S^{a}$ & M.I $^{\mathbf{b}}$ & \%Survival ${ }^{\mathrm{c}}$ & Mean \pm SD $^{a}$ & M.I $^{\mathbf{b}}$ & $\%$ Survival $^{\mathrm{c}}$ \\
\hline \multirow[t]{7}{*}{ TA97 } & 0 & $341 \pm 41$ & 1.0 & 100 & $202 \pm 8$ & 1.0 & 100 \\
\hline & $1: 128$ & $321 \pm 91$ & 0.9 & 100 & $238 \pm 7$ & 1.2 & 100 \\
\hline & $1: 64$ & $319 \pm 42$ & 0.9 & 100 & $116 \pm 22$ & 0.6 & 100 \\
\hline & $1: 32$ & $335 \pm 15$ & 1.0 & 100 & $265 \pm 37$ & 1.3 & 100 \\
\hline & $1: 16$ & $238 \pm 47$ & 0.7 & 100 & $287 \pm 22$ & 1.4 & 100 \\
\hline & $1: 8$ & $233 \pm 59$ & 0.7 & 95 & $240 \pm 6$ & 1.2 & 100 \\
\hline & $\mathrm{PC}$ & $2162 \pm 499$ & 6.3 & 70 & $2388 \pm 399$ & 11.8 & 78 \\
\hline \multirow{7}{*}{ TA98 } & 0 & $19 \pm 3$ & 1.0 & 100 & $51 \pm 4$ & 1.0 & 100 \\
\hline & $1: 128$ & $25 \pm 4$ & 1.3 & 100 & $59 \pm 5$ & 1.1 & 100 \\
\hline & $1: 64$ & $35 \pm 5$ & 1.9 & 100 & $52 \pm 0$ & 1.0 & 100 \\
\hline & $1: 32$ & $29 \pm 2$ & 1.5 & 97 & $65 \pm 3$ & 1.3 & 100 \\
\hline & $1: 16$ & $31 \pm 8$ & 1.6 & 76 & $53 \pm 6$ & 1.0 & 100 \\
\hline & $1: 8$ & $13 \pm 3$ & 0.7 & 100 & $69 \pm 1$ & 1.3 & 100 \\
\hline & $\mathrm{PC}$ & $322 \pm 146$ & 17.3 & 94 & $239 \pm 12$ & 4.7 & 82 \\
\hline \multirow[t]{7}{*}{ TA100 } & 0 & $115 \pm 15$ & 1.0 & 100 & $221 \pm 9$ & 1.0 & 100 \\
\hline & $1: 128$ & $109 \pm 8$ & 1.0 & 100 & $228 \pm 14$ & 1.0 & 100 \\
\hline & $1: 64$ & $137 \pm 13$ & 1.2 & 100 & $242 \pm 31$ & 1.1 & 100 \\
\hline & $1: 32$ & $118 \pm 15$ & 1.0 & 100 & $266 \pm 20$ & 1.2 & 100 \\
\hline & $1: 16$ & $108 \pm 1$ & 0.9 & 100 & $281 \pm 30$ & 1.3 & 100 \\
\hline & $1: 8$ & $111 \pm 12$ & 1.0 & 100 & $260 \pm 0$ & 1.2 & 100 \\
\hline & $\mathrm{PC}$ & $593 \pm 214$ & 5.2 & 86 & $986 \pm 61$ & 4.5 & 85 \\
\hline \multirow[t]{7}{*}{ TA102 } & 0 & $341 \pm 41$ & 1.0 & 100 & $483 \pm 87$ & 1.0 & 100 \\
\hline & $1: 128$ & $374 \pm 7$ & 1.1 & 88 & $599 \pm 63$ & 1.2 & 100 \\
\hline & $1: 64$ & $336 \pm 30$ & 1.0 & 90 & $639 \pm 26$ & 1.3 & 100 \\
\hline & $1: 32$ & $287 \pm 18$ & 0.8 & 90 & $383 \pm 49$ & 0.8 & 100 \\
\hline & $1: 16$ & $264 \pm 9$ & 0.8 & 100 & $911 \pm 64$ & 1.9 & 100 \\
\hline & $1: 8$ & $267 \pm 4$ & 0.8 & 100 & $859 \pm 33$ & 1.8 & 100 \\
\hline & $\mathrm{PC}$ & $2163 \pm 499$ & 6.3 & 75 & $1747 \pm 260$ & 3.6 & 81 \\
\hline
\end{tabular}

${ }^{a}$ Number or revertant colonies per plate: mean values and standard deviation (SD) of at least three experiments; ${ }^{\mathrm{b}}$ MI: Mutagenic index: number of $\mathrm{His}^{+}$induced in the sample/number of spontaneous $\mathrm{His}^{+}$in the negative control; ${ }^{\mathrm{c}}$ Survival calculated in relation to the negative control. Concentration 0 refers to the negative control (solvent): $100 \mu \mathrm{L}$ of DMSO. The doses of the positive controls (PC) per plate in the absence of S9 mix were $0.5 \mu \mathrm{g}$ of 4-nitroquinoline1-oxide to TA97 and TA98; $1.0 \mu \mathrm{g}$ of Sodic Azide to TA100 and $0.5 \mu \mathrm{g}$ of Mitomicin C to TA102. The doses per plate of the positive controls in the presence of S9 mix were $1 \mu \mathrm{g}$ of 2-Aminoantracen to TA97 and TA100 and $20 \mu \mathrm{g}$ of Benzo[ $\alpha]$ piren to TA98 and TA102. Cytotoxicity was detected when survival rates $<70 \%$.

by our group demonstrated that the mean of carotenes in the industrial CPO processed in Bahia were $526.77 \mu \mathrm{g} \cdot \mathrm{g}^{-1}$ (Almeida et al., 2013) and this carotenoid value is extremely high when compared to other oils: sunflower $\left(8.5 \pm 0.7 \mathrm{mg} \cdot \mathrm{L}^{-1}\right)$ and extra virgin olive oil $\left(11.0 \pm 0.3 \mathrm{mg} \cdot \mathrm{L}^{-1}\right.$ ) (Andreu-Sevilla et al., 2008). On the other hand, CPO contains unusually high levels of tocotrienols (Norhaizan et al., 2013; Berger, 2005). Most other common vegetable oils have negligible contents of tocotrienols (Lin, 2011). In CPO, the presence of these antioxidants seems to offer some oxidative protection to the oil through a mechanism in which they are oxidized prior to triglycerides (Lin, 2011). Together with CPO constitution factors, the baiana de acarajé practice of heating oil in the presence of a whole onion considerably preserves the oil quality with a significant reduction in the levels of lipid peroxidation indicators as well as a reduction in tocoferol loss (Oyewole and Olayinka, 2007).

\section{CONCLUSIONS}

In despite of its high TPC levels, no cytotoxic, mutagenic or genotoxic activities were detected in the crude palm oil used in the traditional akara 
Toxicological assessment of crude palm oil (Elaeis guineensis) used in deep frying of akara (cowpea paste finger food) $\bullet 7$

TABLE 3. Micronucleus induction assay in macrophages using CPO and FPO

\begin{tabular}{lccccc}
\hline Samples & Concentration & \%o Mi.I. \pm SD $^{1}$ & \% Apoptosis & \% Necrosis & \% Micronucleus $\mathbf{E S D}$ \\
\hline CPO & NC & $7.9 \pm 2.8$ & $3.6 \pm 1.2$ & $1.0 \pm 0.3$ & $3.8 \pm 1.2$ \\
& $1: 128$ & $4.4 \pm 1.4$ & $1.7 \pm 0.9$ & $1.0 \pm 0.2$ & $3.2 \pm 0.3$ \\
& $1: 64$ & $4.5 \pm 0.8$ & $1.4 \pm 0.5$ & $0.8 \pm 0.3$ & $3.0 \pm 1.5$ \\
$1: 32$ & $11.6 \pm 0.4$ & $2.7 \pm 2.8$ & $0.6 \pm 0.5$ & $2.9 \pm 1.3$ \\
& $1: 16$ & $8.4 \pm 0.8$ & $3.5 \pm 0.2$ & $1.2 \pm 0.3$ & $4.4 \pm 0.6$ \\
& $1: 8$ & $8.9 \pm 1.5$ & $2.8 \pm 0.5$ & $0.8 \pm 0.2$ & $4.1 \pm 1.3$ \\
FPO & PC & $6.7 \pm 1.9$ & $4.7 \pm 0.8$ & $1.2 \pm 0.1$ & $7.9 \pm 1.1$ \\
& NC & $7.9 \pm 2.8$ & $3.6 \pm 1.2$ & $1.0 \pm 0.3$ & $3.8 \pm 1.2$ \\
& $1: 128$ & $5.0 \pm 0.9$ & $1.9 \pm 0.3$ & $0.9 \pm 0.4$ & $3.0 \pm 0.6$ \\
& $1: 64$ & $6.4 \pm 0.1$ & $1.9 \pm 1.8$ & $0.6 \pm 0.4$ & $2.8 \pm 1.2$ \\
& $1: 32$ & $6.0 \pm 3.2$ & $1.7 \pm 0.9$ & $0.7 \pm 0.2$ & $2.6 \pm 0.3$ \\
& $1: 16$ & $5.4 \pm 3.4$ & $1.5 \pm 0.5$ & $1.0 \pm 0.2$ & $1.9 \pm 0.6$ \\
& $1: 8$ & $6.4 \pm 3.1$ & $1.5 \pm 0.2$ & $0.9 \pm 0.4$ & $2.8 \pm 1.4$ \\
& PC & $6.7 \pm 1.9$ & $4.7 \pm 0.8$ & $1.2 \pm 0.1$ & $7.9 \pm 1.1$ \\
\hline
\end{tabular}

${ }^{1}$ Mitotic index per thousand. The doses of the negative and positive controls were $10 \%$ of DMSO and $0.5 \mu \mathrm{M}$ of MNNG, respectively. The experiment was performed in quintuplicate.

TABLE 4. Total polar compound (TPC) content ( $\% \mathrm{w} / \mathrm{w})$ of crude palm oil during $25 \mathrm{~h}$ of akara frying. 5 days, 5 h/day

\begin{tabular}{lccc}
\hline Time (h) & Mean & Std. Error & $\mathbf{\%}^{\mathbf{a}}$ \\
\hline $\mathbf{0}^{\mathbf{b}}$ & 14.08 & 0.04 & - \\
5 & 20.25 & 1.09 & 44.12 \\
10 & 20.09 & 0.40 & 42.68 \\
15 & 24.73 & 0.17 & 75.63 \\
20 & 27.51 & 0.22 & 95.38 \\
$\mathbf{2 5}^{\mathbf{c}}$ & 29.81 & 0.48 & 111.71 \\
\hline
\end{tabular}

${ }^{\mathrm{a}}$ The percentage of increase in TPC after $25 \mathrm{~h}$ of frying; ${ }^{\mathrm{b}} \mathbf{C P O}$ (crude palm oil), initial sample; ${ }^{c} \mathbf{F P O}$ (frying palm oil), final sample.

frying process. This may be due to the CPO natural antioxidant content and akara frying practices such as the addition of an onion to the frying oil, and fresh oil replacement at the beginning. Therefore, the CPO used in akara deep-frying do not offer toxicological risks to consumers.

\section{ACKNOWLEDGMENTS}

The authors were supported by Coordenação de Aperfeiçoamento de Pessoal de Nível Superior (CAPES), Conselho Nacional de Desenvolvimento Científico e Tecnológico (CNPq, Process n 482790/ 2010-5, Brazil), Fundação de Amparo à Pesquisa do Estado do Rio de Janeiro (FAPERJ) and SR2/ UERJ, FAPESB (Termo N: BOL1784/2010, Brazil),
Associação das Baianas de Acarajés e Mingau da Cidade de Salvador-Bahia-Brazil and Alessandra Quirino for technical assistance.

\section{REFERENCES}

Adam SK, Das S, Jaarin K. 2009. A detailed microscopic study of the changes in the aorta of experimental model of postmenopausal rats fed with repeatedly heated palm oil. Int. J. Exp. Path. 90, 321-327. http://dx.doi. org/10.1111/j.1365-2613.2009.00658.x.

Aiub C, Pinto LFR, Felzenszwalb I. 2003. N-Nitrosodiethylamine mutagenicity at low concentrations. Toxicol. Lett. 145, 36-45. http://dx.doi.org/10.1016/S0378-4274(03)00263-7.

Aiub C, Gadermaier G, Oliveira I, Felzenszwalb I, Ferreira F, Pinto LFR, Eckl P. 2011. N-Nitrosodiethylamine genotoxicity in primary rat hepatocytes: effects of cytochrome P450 induction by phenobarbital. Toxicol. Lett. 206, 2, 139-143. http://dx.doi.org/10.1016/j.toxlet.2011.07.002.

Almeida DT, Nunes IL, Conde PL, Rosa RPS, Rogério WF, Machado ER. 2013. A quality assessment of crude palm oil marketed in Bahia, Brazil. Grasas Aceites 64, 384-394. http://dx.doi.org/10.3989/gya.118412.

Andreu-Sevilla A, Hartmann A, Sayas E, Burló-Carbonell F, Delgado-Estrell P, Valverde J. 2008. Mathematical quantification of total carotenoids in Sioma oil using color coordinates and multiple linear regression during deep-frying simulations. Eur. Food Res. Technol. 226, 1283-1291. http:// dx.doi.org/10.1007/s00217-007-0656-2.

Berger KG. 2005. The use of palm oil in frying. Frying oil series. Malaysian Palm Oil Promotion Council (MPOPC) [Online]. Available: http://www.mpoc.org [19 Jun 2013].

Carpes RM, Fleury BG, Lages BG, Pinto AC, Aiub CA, Felzenszwalb I. 2013. Mutagenicity, genotoxicity, and scavenging activities of extracts from the soft coral Chromonephthea braziliensis: a possibility of new bioactive compounds. Genet. Mol. Res. 12, 3575-3587. http:// dx.doi.org/10.4238/2013.September.13.2.

Claxton LD, Allen J, Auletta A, Mortelmans K, Nestmann E,Zeiger E. 1987. Guide for the Salmonella typhimurium/Mammalian 
Microsome Tests for Bacterial Mutagenicity. Mutat. Res. 189, 83-91. http://dx.doi.org/10.1016/0165-1218(87)90014-0.

DeMarco E, Saravese M, Parisini C, Battimo I, Falco S, Sacchi, R. 2007. Frying performance of a sunflower/palm oil blend in comparison with pure palm oil. Eur. J. Lipids Sci. Technol. 109, 237-246. http://dx.doi.org/10.1002/ejlt.200600192.

Dobarganes MC, Márquez-Ruiz G, Velasco J. 2000a. Interactions between fat and food deep-frying. Eur. J. Lipid Sci. Technol. 102, 521-528. http://dx.doi.org/10.1002/1438-9312(200009) 102:8/9<521::AID-EJLT521>3.0.CO;2-A.

Dobarganes MC, Velasco J, Dieffenbacher A. 2000b. Determination of polar compounds polymerized and oxidized triacylglycerols, and diacylglycerols in oils and fats. Pure Appl. Chem. 72, 1563-1575. http://dx.doi.org/10.1351/pac200072081563.

González-Muñoz MJ, Bastida S, Sánchez-Muniz FJ. 1998. Short-Term in Vivo Digestibility of Triglyceride Polymers, Dimers, and Monomers of Thermoxidized Palm Olein Used in Deep-Frying. J. Agric. Food Chem. 46, 5188-5193. http://dx.doi.org/10.1021/jf980598i.

Farag RS, Abdel-Latif MS, Basuny AMM, Hakeem BSAE. 2010. Effect of non-fried and fried oils of varied fatty acid composition on rat organs. Agric. Biol. J. N Am. 1, 501-509.

Fong LYY, Ton CCT, Koonaunwatchaidet P, Huang DP. 1980. Mutagenicity of peanut oils and effect of repeated cooking. Food Cosmet. Toxicol. 18, 467-470. http://dx.doi. org/10.1016/0015-6264(80)90158-3.

Hageman G, Kikken R, Ten Hoor F, Kleinjans J. 1988. Assessment of mutagenic activity of repeatedly used deepfrying fats. Mutat. Res. 204, 595-604.

IPHAN-Instituto do Patrimônio Histórico e Artístico Nacional, DOSSIÊ IPHAN 6, Ofício das Baianas do Acarajé. 2005. Ministério da Cultura, DF, Brasil [Online]. Available: http// portal.iphan.gov.br/portal/baixaFcdAnexo.do?id=919 [30 Apr 2013].

Isong EU, Ebong PE, Ifon ET, Umoh IB, Eka OU. 1997. Thermoxidized palm oil induces reproductive toxicity in healthy and malnourished rats. Plant Food Hum. Nutr. 51, 159-166. http://dx.doi.org/10.1023/A:1007922308985.

Jorge N, Gonçalves AG. 1998. Comportamento do óleo de girassol, com alto teor de ácido oléico em termoxidação e fritura. Ciência Tecnol. Alim. 18, 335-342.

Lin SW. 2011. Palm oil. In Gunstone FD (Ed.). Vegetable oils in food technology, composition, properties and use, $1^{\text {th }}$ edition, Iowa, Blackwell Publishing, 59-93. http://dx.doi. org/10.1002/9781444339925.ch2.

Maron DM, Ames BN. 1983. Revised methods for the Salmonella mutagenicity test. Mutat. Res. 113, 173-215. http://dx.doi.org/10.1016/0165-1161(83)90010-9.

Matthäus B, 2007. Use of palm oil for frying in comparison with other high-stability oils. Eur. J. Lipids Sci. Technol. 109, 400-409. http://dx.doi.org/10.1002/ejlt.200600294.

Morita O, Tamaki Y, Kirkpatrick JB, Chengelisb CP. 2008. Safety assessment of heated diacylglycerol oil, Subchronic toxicity study in rats. Food Chem. Toxicol. 46, 2748-2757. http://dx.doi.org/10.1016/j.fct.2008.06.008.
Mortelmans K, Zeiger E. 2000. The Ames Salmonella/microsome mutagenicity assay. Mutat. Res. 455, 29-60. http:// dx.doi.org/10.1016/S0027-5107(00)00064-6.

Norhaizan ME, Hosseini S, Gangadaran S, Lee ST, Kapourchali FR, Moghadasian MH. 2013. Palm oil, Features and applications. Lipid Tecnol. 25, 39-42. http://dx.doi.org/10.1002/ lite. 201300254.

Oliveira HP. 2009. Dendê, aspectos botânicos, agronômicos, ecológicos e econômicos. In Loddy R (Ed.). Dendê símbolo e sabor, São Paulo, Editora SENAC, 52-82.

Oyewole OI, Olayinka ET. 2007. Protective role of onion and garlic on physicochemical alterations and toxicity of heated soybean oil. Afr. J. Biotechnol. 6, 2158-2161.

Pantzaris TP. 1998. Comparison of monounsaturated and polyunsaturated oils in continuous frying. Grasas Aceites 49, 319-352. http///dx doi.org/10.3989/gya 1998 v49 i3-4.733.

Reber EF, Eboh L, Aladeselu A, Brown WA, Marshall DD. 1983. Development of high-protein low-cost Nigerian foods. J. Food Sci. 48, 217. http://dx.doi.org/10.1111/j.1365-2621. 1983.tb14827.x.

Rogério WF. 2010. Uma imersão no tabuleiro da baiana: o acarajé. Master's thesis (MSc), Federal University of Bahia, School of Nutrition, Salvador-BA. [Online]. $103 \mathrm{f}$. http://www. repositorio.ufba.br/ri/handle/ri/10491.

Saguy IS, Dana D. 2003. Integrated approach to deep fat frying, engineering, nutrition, health and consumer aspects. $J$. Food Eng. 56, 143-152.

Sampaio KA, Ayala JV, Silva SM, Ceriani R, Verhe R, Meirelles AJA. 2013. Thermal Degradation Kinetics of Carotenoids in Palm Oil. J. Am. Chem. Soc. 90, 191-198.

Scheutwinkel-Reich M, Ingerowski G, Stan HJ. 1981. Microbiological studies investigating mutagenicity of deep frying fat fractions and some of their components. Lipids 15, 849-852. http://dx.doi.org/10.1007/ BF02534375.

Soriano JM, Moltó, JC, Mañes J. 2002. Hazard analysis and critical control points in deep-fat frying. Eur. J. Lipid Sci. Technol. 104, 174-177. http://dx.doi.org/10.1002/14389312(200203)104:3<174::AID-EJLT174>3.0.CO;2-7.

Stankevicins L, Aiub C, Santa Maria LC, Lobo-Hajdu G, Felzenszwalb I. 2008. Genotoxic and antigenotoxic evaluation of extracts from Arenosclera brasiliensis, a Brazilian marine sponge. Toxicol. in Vitro 22, 1869-1877. http:// dx.doi.org/10.1016/j.tiv.2008.09.003.

Taylor SL, Berg CM, Shoptaugh NH, Scott VN. 1982. Lack of mutagens in deep-fat-fried foods obtained at the retail level. Food Chem. Toxic. 20, 209-212. http://dx.doi.org/10.1016 /S0278-6915(82)80250-0.

Van Gastel A, Mathur R, Roy VV, Rukmirfi C. 1984. Ames mutagenicity test of repeatedly heated edible oils. Food Chem. Toxic. 22, 403-405. http://dx.doi. org/10.1016/0278-6915(84)90371-5.

Velasco J, Marmesat S, Dobarganes MC. 2008. Chemistry of frying. In Sahin S, Sumnu SG (Ed.). Advances in deepfat frying of foods, London (NY), CRC Press, Taylor \& Francis Group, Boca Raton, 33-56. 